\begin{tabular}{|c|c|c|}
\hline & Int.J.Curr.Microbiol.App.Sci (2021) 10(12): 258-267 & \\
\hline & $\begin{array}{l}\text { International Journal of Current Microbiology and Applied Sciences } \\
\text { ISSN: 2319-7706 Volume } 10 \text { Number } \mathbf{1 2} \mathbf{( 2 0 2 1 )} \\
\text { Journal homepage: http://www.ijcmas.com }\end{array}$ & $\$ 0$ \\
\hline $\begin{array}{l}\text { EXCELLENT } \\
\text { PUBLISHERS }\end{array}$ & & \\
\hline
\end{tabular}

\title{
Quantitative Morphometric Analysis using RS and GIS techniques in VNMKV-Pingali Watershed of Pingalgarh Nala Catchment, Parbhani District, Maharashtra, India
}

\author{
A. B. Phupate ${ }^{1 *}$, V. K. Ingle ${ }^{1}$, H. W. Awari ${ }^{1}$, U. M. Khodke ${ }^{1}$, \\ S. B. Jadhav ${ }^{1}$ and M. S. Pendke ${ }^{2}$ \\ ${ }^{1}$ Department of Irrigation and Drainage Engineering, ${ }^{2}$ Department of Soil and Water \\ Conservation Engineering, College of Agriculture Engineering and Technology, V.N.M.K.V., \\ Parbhani, Maharashtra, India \\ *Corresponding author
}

\section{Keywords}

Watershed, DEM, Morphometric Analysis, Linear Aspect, Aerial Aspect, Relief Aspect

Article Info

Received: 12 November 2021 Accepted: 06 December 2021 Available Online: 10 December 2021

\section{A B S T R A C T}

Watershed is a region (or area) delineated with a well-defined topographic boundary and outlets. It is a region within which hydrological conditions are such that water becomes concentrated within a particular location. The morphometric characteristics at the watershed scale may contain important information regarding its formation and development because all hydrologic and geomorphic processes occur within the watershed (Singh, 1992). The quantitative analysis of morphometric parameters is found to be of immense utility in river basin evaluation, watershed prioritization for soil and water conservation and natural resources management at watershed level. DEMs can be used to derive flow networks and then automatically generate watershed boundaries for given outlet points using GIS technology. Morphometric analysis of the watershed is characterized by dendritic type drainage basin which indicates the homogeneity in texture and lack of structural control VNMKV- Pingali watershed has order up to $5^{\text {th }}$ order. From first (272.97) to fifth order $(0.22)$ stream, stream length decreases hence gradient is increased from flat to steep as the stream order increases. The mean stream length ratio varies between 0.13 to 0.25 . The increase in stream length ratio from lower to higher order shows that the study area has reached a mature geographic stage. The drainage density of the watershed is $1.88 \mathrm{Km} / \mathrm{Km}^{2}$. A low drainage density indicates permeable subsurface strata and is a characteristic feature of coarse drainage which generally shows values less than 5.0. A low value of the drainage density indicates a relatively low density of streams and thus a slow stream response (Singh, 2004). The Ruggedness number for the basin is 1.46 . This number represents that if drainage density is increased, keeping relief as constant then average horizontal distance from drainage divide to the adjacent channel is reduced. 


\section{Introduction}

A watershed is made up of its physical and hydrological natural resources as human resources. Now a day, digital elevation models (DEM) are being widely used for watershed delineation, extraction of stream networks and characterization of watershed topography (LULC map, slope map and elevation map) by using watershed delineation tool in GIS software. Digital elevation models (DEMs) are grid-based GIS coverages that represent elevation. The quantitative analysis of morphometric parameters is found to be of immense utility in river basin evaluation, watershed prioritization for soil \& water conservation and natural resources management at watershed level. The measurement of morphological parameters is laborious by the conventional methods, but using the latest technology like GIS, the morphometric analysis of natural drain and its drainage network can be better achieved. Various morphometric parameters need to measure in a drainage basin include stream order, stream length, stream number and basin area.

The morphometric characteristics at the watershed scale may contain important information regarding its formation and development because all hydrologic and geomorphic processes occur within the watershed (Singh, 1992). The quantitative analysis of morphometric parameters is found to be of immense utility in river basin evaluation, watershed prioritization for soil and water conservation and natural resources management at watershed level. The influence of drainage morphometric is very significant in understanding the landform processes, physical properties of soil and erosional characteristics. Drainage characteristics of many river basins and sub basins in different parts of the globe have been studied using conventional methods (Horton, 1945; Strahler,
1957, 1964: Krishnamurthy et al., 1996). Geographical Information System (GIS) techniques are now a day used for assessing various terrain and morphometric parameters of the drainage basins and watersheds.

Said and Siddique et al., (2018) carried out Morphometric analysis and sub-watersheds prioritization of Nagmati River watershed, Kutch District, Gujarat using GIS based approach study and it evaluates the quantitative morphometric characteristics of Nagmati River watershed in Kutch District of Gujarat by utilizing Cartosat-1 data (CartoDEM). Prioritization of the watershed is one of the important aspects of planning for implementation of its development and management programs. The present study demonstrates the usefulness of remote sensing and GIS for morphometric analysis, prioritization of the sub-watersheds and hypsometric analysis of Nagmati watershed in Kutch district, Gujarat, India. The morphometric characteristics of different subwatersheds show their relative characteristics with respect to hydrologic response of the watershed. The drainage pattern of the stream network reveals a dendritic type with sixth order stream network which is indicative of homogeneity in texture and lack of structural control.

Chandra and Milind Gidde (2019) conducted morphometric analysis of Baltira Watershed using QGIS Platform. The objective of the study was to perform morphometric analysis for Baltira watershed, Maharashtra, India. In this study, a detailed morphometric assessment is done by QGIS for Baltira watershed which covers an area of $273 \mathrm{~km}^{2}$. Baltira is one of the tributaries of Man River. The result of morphometric analysis reveals that watershed of Baltira in which geology is reasonably homogeneous has high relief and steep ground slope. For this study, ASTERDEM is utilized for watershed delineation and 
drainage parameter calculation by the hydrological module of QGIS software. From the results, it can be observed that the SW5 and SW10 are having the highest and lowest relief respectively amongst all the subwatersheds.

\section{Study Area and Data used}

\section{Study Area}

The present work is conducted at VNMKV campus, District -Parbhani, Maharashtra. The study area VNMKV -Pingali watershed lies between $19^{\circ} 15^{\prime} \mathrm{N}$ Latitude and $76^{\circ} 46^{\prime} \mathrm{E}$ longitude. Geographical area of watershed is $344.13 \mathrm{~km}^{2}$. A study area is central part the of the Pingalgarh Nala catchment which is part of Godavari Purna river basin. The middle part of this watershed is covered by Vasantrao Naik Marathwada Krishi Vidyapeeth (VNMKV) university campus and Pingali village is situated at outlet of this watershed hence nomenclature of the study area watershed is as VNMKV-Pingali watershed, whereas the area of selected watershed is $169.79 \mathrm{~km}^{2}$. Location map of study area is given in figure 1.1 DEM characterizes the topography of the region by portraying the elevation of any point at any specific location. The original DEM file was acquired from Bhuvan portal of National Remote Sensing Centre, which is initially generated using IRS Satellite Cartosat-1 images.

\section{Morphometric Analysis}

Morphometry literally means measurements of forms introducing quantitative description of land form. It is the analysis of measurement and mathematical evaluation of earth's surface, shape and dimension of its landforms (obi Reddy et al., 2002). The morphometric examination of the basin is achieved through competition linear, aerial and relief of channel network (Table.1).

\section{Results and Discussion}

\section{Morphometric Analysis}

\section{Linear Aspects}

Total number of 808 streams are identified of which 662 are $1^{\text {st }}$ order streams, 119 are 2 nd order, 21 are 3 rd order, 5 is indicating 4th order and 1 is $5^{\text {th }}$ order stream. Total length of 1st order streams is $272.97 \mathrm{Km}$, 2nd order streams is $38.81 \mathrm{Km}$, 3rd order streams is 6.46 $\mathrm{Km}$, 4th order stream is $1.63 \mathrm{Km}$ and $5^{\text {th }}$ order stream is $0.22 \mathrm{~km}$.

The mean stream length of the watershed is found to be $0.41,0.32,0.30,0.32$ and $0.22 \mathrm{~km}$ for $1 \mathrm{st}$, 2nd $3 \mathrm{rd}$, 4th and $5^{\text {th }}$ order streams respectively. Stream length ratio for the basin varies between 0.13 to 0.25 .The stream length ratio (RL) is estimated of $0.14,0.16,0.25$ and 0.13 for II/I, III/II, IV/III and IV/V orders, respectively. In the present study, $\mathrm{Rb}$ varies from 4.2 to 5.66 with an average of 5.10.

It is estimated of 5.56, 5.66, 4.2 and 5 for I/II, II/III, III/IV and IV/V orders, respectively. Rb is not same from one order to its next order. It also indicates that the value of $\mathrm{Rb}$ is not same from one order to next order. The higher value of $\mathrm{Rb}$ indicated strong structural control on the drainage pattern.

This shows its usefulness for hydrograph shape for watersheds similar in other respect. An elongated watershed has higher bifurcation ratio than normal and approximately circular watershed (Singh, 2003). It is indicated that the watershed chosen for the study is not circular in shape and would produce delayed peak flow. Basin length of basin is $23.58 \mathrm{Km}$. It is the longest length of basin from the head water to the point of confluence.

\section{Areal Aspects}

The form factor for the study area is 0.30 . For 
perfectly circular basin it should be greater than 0.78. Smaller the value of form factor more will be elongated basin and flatter peak flow for longer durations hence it has highest peak discharge in the catchment. The value of Circulatory ratio for the watershed is 0.22 . The value of Rc is imply that basin shape is elongated with low flood risk of longer lag time having young stage of topography, runoff discharge is minimal and subsurface permeability is high. The elongation ratio of watershed is 0.62 . The varying slopes of watershed can be classified with the help of the index of elongation ratio, i.e. circular (0.9$0.10)$, oval (0.8-0.9), less elongated (0.7-0.8), elongated (0.5-0.7), and more elongated $(<0.5)$. It is observed that the watershed is elongated. The stream frequency of the watershed is 4.75 . The value of stream frequency (Fs) for the basin exhibit positive correlation with the drainage density value of the area indicating the increase in stream population with respect to increase in drainage density. The stream frequency is dependent more or less on the rainfall and the temperature of the region. The drainage density of the watershed is $1.88 \mathrm{Km} / \mathrm{Km}^{2}$. A low drainage density indicates permeable subsurface strata and is a characteristic feature of coarse drainage which generally shows values less than 5.0. A low value of the drainage density indicates a relatively low density of streams and thus a slow stream response (Singh, 2004). Drainage texture is one of the important concepts of geomorphology which means the relative spacing of drainage lines. Value of Constant of channel maintenance $(C)$ for the basin is $0.53 \mathrm{Km}$ which is reciprocal of drainage density. The term "length of overland flow" is used to describe the length of flow of water over the ground before it becomes concentrated in definite stream channels. The length of overland flow is 1.06. The watershed is having less structural disturbances, having higher overland flow

\section{Relief Aspects}

The maximum relief for the watershed is 0.78 $\mathrm{Km}$. Relative relief for the watershed is 0.008 . The relief ratio for basin is 0.03 . Watershed area indicates the presence of basement rocks that are exposed in the form of small ridges and mounds with lower degree of slope. The Rh normally increased with the decreasing drainage area and size of the watersheds for a given drainage basin (Gottschalk, 1964). It measures overall steepness of watershed and also considered as an indicator for the intensity of erosion process occurring in the watershed. The high value of relief ratio is characteristics of hilly region. The Ruggedness number for the basin is $214.5 \mathrm{Km}$. This number represents that if drainage density is increased, keeping relief as constant then average horizontal distance from drainage divide to the adjacent channel is reduced. On the other hand, if relief increases by keeping drainage density as constant, the elevation difference between the drainage divide and adjacent channel will increase.

GIS has proved to be an efficient tool in drainage delineation and this drainage has been used in the present study. Delineation \& mapping VNMKV-Pingali watershed with GIS done in this project. Watershed delineation will give watershed boundary for that particular stream.GIS have helped us to understand various terrain parameters such as nature of bedrock, infiltration surface runoff etc. Morphometric analysis is carried out through updated drainage. Linear, aspects, areal aspects and relief aspects of the basin are measured for the analysis.GIS have helped us to understand various terrain parameters such as nature of bedrock, infiltration surface runoff etc. 
Table.1 Morphometric Parameters with Formulae

\begin{tabular}{|c|c|c|c|}
\hline Sr.No. & $\begin{array}{l}\text { Morphometric } \\
\text { Parameters }\end{array}$ & Methodology & Reference \\
\hline & \multicolumn{3}{|c|}{ Linear } \\
\hline 1. & Area & GIS Analysis & \\
\hline 2. & Perimeter & GIS Analysis & \\
\hline 3. & Stream order $(\mathrm{u})$ & Hierarchical Order & Strahler, 1964 \\
\hline 4. & Stream Number $(\mathrm{Nu})$ & GIS Analysis & Horton, 1945 \\
\hline 5. & Stream Length (Lu) & Length of the Stream in $\mathrm{km}$ & Horton, 1945 \\
\hline 6. & $\begin{array}{l}\text { Mean Stream Length } \\
\text { (Lsm) }\end{array}$ & $\begin{array}{l}\mathrm{Lsm}=\mathrm{Lm} / \mathrm{Nm} \text {, Where, } \mathrm{Lm}=\text { Total } \\
\text { stream length of order ' } \mathrm{m} \text { ' and } \mathrm{Nm}= \\
\text { Total no. of streams of order ' } \mathrm{m} \text { ' }\end{array}$ & Horton, 1945 \\
\hline 7. & $\begin{array}{l}\text { Stream Length Ratio } \\
\text { (RL) }\end{array}$ & $\begin{array}{c}\mathrm{RL}=\mathrm{Lsm} / \mathrm{Lsm}-1 \text {, Where, Lsm= Mean } \\
\text { stream length of a given order 'm', } \\
\mathrm{Lsm}-1=\text { Mean stream length of next } \\
\text { lower order 'm-1' }\end{array}$ & Horton, 1945 \\
\hline 8. & Bifurcation Ratio (Rb) & $\begin{array}{l}\mathrm{Rb}=\mathrm{Nm} / \mathrm{Nm}+1 \text {, Where, } \mathrm{Nm}=\mathrm{No} \text { of } \\
\text { streams of a given order ' } \mathrm{m} \text { ', } \mathrm{Nm}+1= \\
\text { No. of stream segments of next higher } \\
\text { order }\end{array}$ & Schumn, 1956 \\
\hline 9. & Basin length (Lb) & $\begin{array}{l}\mathrm{L}_{b}=1.312 \times \mathrm{A}^{0.568} \text { Where, } \mathrm{L}_{\mathrm{b}}=\text { Basin } \\
\text { Length, } \mathrm{Km} \mathrm{A}=\text { Area of basin, } \mathrm{Km}^{2}\end{array}$ & \\
\hline 10. & $\begin{array}{l}\text { Average basin width } \\
\text { (B) }\end{array}$ & $\begin{array}{c}\mathrm{B}=\mathrm{A} / \mathrm{Lb} \text { Where, } \mathrm{A}=\text { Area of basin, } \\
\mathrm{Km}^{2}, \mathrm{~L}_{\mathrm{b}}=\text { Basin Length, } \mathrm{Km}\end{array}$ & \\
\hline \multicolumn{4}{|c|}{ Areal } \\
\hline 11. & Drainage density (Dd) & $\begin{array}{c}\mathrm{Dd}=\mathrm{L} / \mathrm{A}, \text { Where, } \mathrm{Dd}=\text { Drainage } \\
\text { Density }(1 / \mathrm{Km}), \mathrm{L}=\text { Total stream } \\
\text { length of all orders }(\mathrm{Km}) ; \mathrm{A}=\text { Area of } \\
\text { the basin }\left(\mathrm{Km}^{2}\right)\end{array}$ & Horton, 1945 \\
\hline 12. & $\begin{array}{l}\text { Stream Frequency } \\
\text { (Fs) }\end{array}$ & $\begin{array}{c}\mathrm{Fs}=\mathrm{N} / \mathrm{A}, \text { Where, } \mathrm{Fs}=\mathrm{Stream} \\
\text { Frequency }\left(\text { number } / \mathrm{Km}^{2}\right) ; \mathrm{N}=\text { Total } \\
\text { no. of streams of all orders and } \\
\mathrm{A}=\text { Area of the basin }\left(\mathrm{Km}^{2}\right)\end{array}$ & Horton, 1945 \\
\hline 13. & Texture Ratio (T) & $\begin{array}{l}\mathrm{T}=\mathrm{N} 1 / \mathrm{P}, \mathrm{Where}, \mathrm{N} 1=\text { No. of streams } \\
\text { of } 1 \text { st order; } \mathrm{P}=\mathrm{B} \text { asin perimeter }(\mathrm{Km})\end{array}$ & Horton, 1945 \\
\hline 14. & Form Factor (Rf) & $\begin{array}{c}\mathrm{Rf}=\mathrm{A} / \mathrm{L}_{\mathrm{b}}^{2}, \text { Where, } \mathrm{A}=\text { Area of the } \\
\text { basin }\left(\mathrm{Km}^{2}\right) ; \mathrm{Lb}=\text { Basin length }(\mathrm{Km})\end{array}$ & Horton, 1945 \\
\hline 15. & Drainage texture $(\mathrm{Dt})$ & $\begin{array}{l}\mathrm{Dt}=\mathrm{N} / \mathrm{P}, \mathrm{Where}, \mathrm{N}=\text { No. of streams of } \\
\text { all order; } \mathrm{P}=\text { Basin perimeter }(\mathrm{Km})\end{array}$ & Horton, 1945 \\
\hline 16. & Circulatory Ratio (Rc) & $\begin{array}{c}\mathrm{Rc}=4 \pi \mathrm{A} / \mathrm{P}^{2}, \text { Where, } \mathrm{A}=\text { Basin area } \\
\left(\mathrm{km}^{2}\right) ; \mathrm{P}=\text { Basin perimeter }(\mathrm{Km})\end{array}$ & Miller, 1953 \\
\hline 17. & Elongation Ratio (Re) & $\begin{array}{l}\mathrm{Re}=2 \sqrt{ }(\mathrm{A} / \pi) / \mathrm{Lb}, \text { Where, } \mathrm{A}=\text { Area of } \\
\text { the basin }\left(\mathrm{Km}^{2}\right) ; \mathrm{L}_{b}=\text { Basin length }(\mathrm{K})\end{array}$ & Schumn, 1956 \\
\hline 18. & Channel Maintenance & $\mathrm{C}=1 / \mathrm{Dd}$, Where, $\mathrm{Dd}=$ Drainage & Horton, 1945 \\
\hline
\end{tabular}




\begin{tabular}{|c|c|c|c|}
\hline & constant (C) & Density $\left(\mathrm{Km} / \mathrm{Km}^{2}\right)$ & \\
\hline 19. & $\begin{array}{l}\text { Infiltration Number } \\
\text { (In) }\end{array}$ & $\begin{array}{c}\mathrm{In}=\mathrm{Dd} \times \mathrm{Fs} \text { Where, } \mathrm{Dd}=\text { Drainage } \\
\text { Density }\left(\mathrm{Km} / \mathrm{Km}^{2}\right) ; \mathrm{Fs}=\text { Stream } \\
\text { frequency }\left(\mathrm{Number} / \mathrm{Km}^{2}\right)\end{array}$ & Faniran, 1968 \\
\hline 20. & $\begin{array}{l}\text { Length of Overland } \\
\text { Flow (Lof) }\end{array}$ & $\begin{array}{c}\text { Lof }=1 / 2 \mathrm{Dd} ; \text { Where, } \mathrm{Dd}=\text { Drainage } \\
\text { Density }\left(\mathrm{Km} / \mathrm{Km}^{2}\right)\end{array}$ & Horton, 1945 \\
\hline \multicolumn{4}{|c|}{ Relief } \\
\hline 21. & Basin relief $(\mathrm{H})$ & $\begin{array}{l}\text { Vertical distance between the lowest } \\
\text { and highest points of watershed }\end{array}$ & Schumn, 1956 \\
\hline 22. & Relief Ratio (Rh) & $\begin{array}{c}\mathrm{Rh}=\mathrm{H} / \mathrm{Lb}, \text { Where, } \mathrm{H}=\text { Basin Relief } \\
(\mathrm{Km}) ; \mathrm{Lb}=\text { Basin length }(\mathrm{Km})\end{array}$ & Schumn, 1956 \\
\hline 23. & Relative Relief (Rr) & $\begin{array}{c}\mathrm{Rr}=\mathrm{H} / \mathrm{P}, \text { Where, } \mathrm{H}=\text { Basin relief } \\
(\mathrm{Km}) ; \mathrm{P}=\text { Basin Perimeter }(\mathrm{Km})\end{array}$ & Melton (1957) \\
\hline 24. & $\begin{array}{l}\text { Ruggedness Number } \\
\text { (Rn) }\end{array}$ & $\begin{array}{c}\mathrm{Rn}=\mathrm{H} \times \mathrm{Dd} \text { Where, } \mathrm{H}=\text { Basin Relief } \\
(\mathrm{Km}) ; \mathrm{Dd}=\text { Drainage Density }(\mathrm{Km} / \\
\left.\mathrm{Km}^{2}\right)\end{array}$ & Schumn, 1956 \\
\hline
\end{tabular}

Table.2 Linear Aspect of Morphometry

\begin{tabular}{|c|c|c|c|c|c|c|}
\hline & \multicolumn{5}{|c|}{ Linear Aspect Parameter } & \\
\hline Sr.No & \multicolumn{3}{|c|}{ Morphometric Characteristics } & \multicolumn{2}{|c|}{ Estimated Value } & \\
\hline 1. & \multicolumn{3}{|c|}{$\operatorname{Area}(\mathrm{KM})^{2}$} & \multicolumn{2}{|c|}{169.79} & \\
\hline 2. & \multicolumn{3}{|c|}{ Perimeter(KM) } & \multicolumn{2}{|c|}{96.7} & \\
\hline \multirow[t]{6}{*}{3.} & $\begin{array}{l}\text { Stream } \\
\text { order (u) }\end{array}$ & $\begin{array}{c}\text { No. of } \\
\text { streams(Nu) }\end{array}$ & $\begin{array}{c}\text { Stream } \\
\text { Length(Lu) } \\
\text { KM }\end{array}$ & $\begin{array}{c}\text { Mean } \\
\text { Stream } \\
\text { Length } \\
\text { (Lsm) }\end{array}$ & $\begin{array}{l}\text { Bifurcation } \\
\text { Ratio }\left(\mathrm{R}_{\mathrm{b}}\right)\end{array}$ & $\begin{array}{c}\text { Stream } \\
\text { Length } \\
\text { Ratio (RL) }\end{array}$ \\
\hline & I & 662 & 272.97 & 0.41 & 5.56 & 0.14 \\
\hline & II & 119 & 38.81 & 0.32 & 5.66 & 0.16 \\
\hline & III & 21 & 6.46 & 0.30 & 4.2 & 0.25 \\
\hline & IV & 5 & 1.63 & 0.32 & 5 & 0.13 \\
\hline & V & 1 & 0.22 & 0.22 & & \\
\hline Total & & 808 & 320.10 & 1.59 & & \\
\hline Average & & & & & 5.10 & 0.17 \\
\hline 4 & \multicolumn{2}{|c|}{ Basin Length , $\mathrm{KM}\left(\mathrm{L}_{\mathrm{b}}\right)$} & 2358 & & & \\
\hline 5 & \multicolumn{2}{|c|}{$\begin{array}{l}\text { Average basin } \\
\text { width,KM(B) }\end{array}$} & 7.20 & & & \\
\hline
\end{tabular}


Fig.1 Study area of watershed
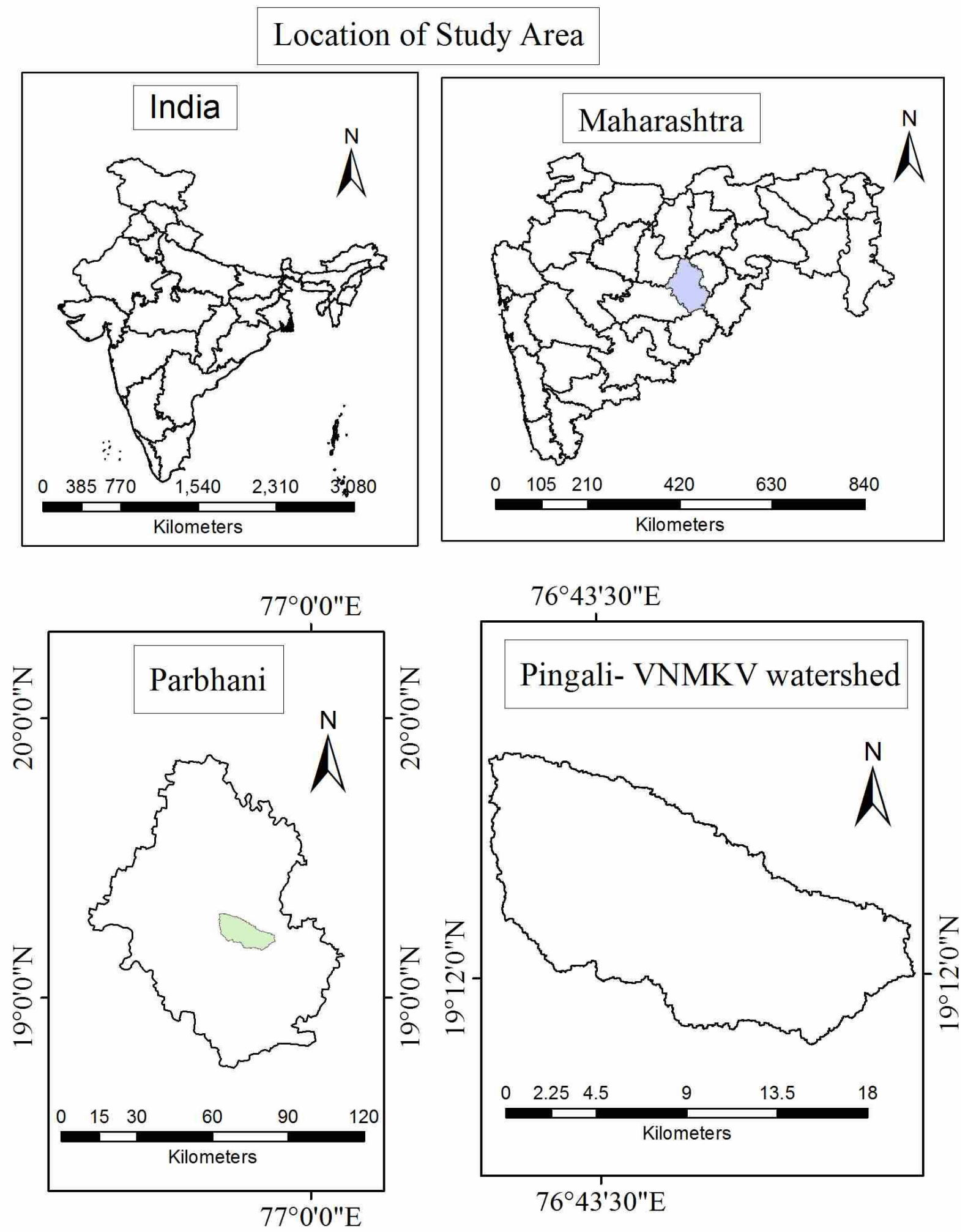
Table.3 Aerial Aspect of morphometry

\begin{tabular}{|c|c|c|c|}
\hline & Aerial Aspect Parameter & & \\
\hline Sr.No. & Morphometriuc Charactristics & Unit & Estimated Value \\
\hline $\mathbf{1}$ & Drainage density $\left(\mathrm{D}_{\mathrm{d}}\right)$ & $(/ \mathrm{KM})$ & 1.88 \\
\hline $\mathbf{2}$ & Stream Frequency $(\mathrm{Fs})$ & $\left(/ \mathrm{KM}^{2}\right)$ & 4.75 \\
\hline $\mathbf{3}$ & Texture Ratio $\left(\mathrm{R}_{\mathrm{t}}\right)$ & & 6.84 \\
\hline $\mathbf{4}$ & Form Factor $(\mathrm{Rf})$ & & 0.30 \\
\hline $\mathbf{5}$ & Drainage texture $(\mathrm{Dt})$ & & 8.35 \\
\hline $\mathbf{6}$ & Circulatory Ratio $(\mathrm{Rc})$ & & 0.22 \\
\hline $\mathbf{7}$ & Elongation Ratio $(\mathrm{Re})$ & & 0.62 \\
\hline $\mathbf{8}$ & Channel Maintenance constant $(\mathrm{C})$ & & 0.53 \\
\hline $\mathbf{9}$ & Infiltration Number $(\mathrm{In})$ & & 8.97 \\
\hline $\mathbf{1 0}$ & Length of Overland Flow $(\mathrm{LoF})$ & & 1.06 \\
\hline
\end{tabular}

Table.4 Relief Aspect of morphometry

\begin{tabular}{|c|c|c|}
\hline & \multicolumn{2}{|c|}{ Relative aspect of watershed } \\
\hline Sr.No. & Morphometric Characteristics & Estimated Value \\
\hline $\mathbf{1}$ & Basin Relief $(\mathrm{H})$ & 0.78 \\
\hline $\mathbf{2}$ & Relief Ratio $(\mathrm{Rh})$ & 0.03 \\
\hline $\mathbf{3}$ & Relative Relief $(\mathrm{Rr})$ & 0.008 \\
\hline $\mathbf{4}$ & Ruggedness number $(\mathrm{Rn})$ & 1.46 \\
\hline
\end{tabular}

Morphometric analysis of the watershed is characterized by dendritic type drainage basin which indicates the homogeneity in texture and lack of structural control.-VNMKV Pingali watershed has order up to $5^{\text {th }}$ order. From first (272.97) to fifth order (0.22) stream, stream length decreases hence gradient is increase from flat to steep as the stream order increases. The mean stream length ratio varies between 0.13 to 0.25 . The increase in stream length ratio from lower to higher order shows that the study area has reached a mature geographic stage. The higher value (5.66) of the mean bifurcation ratio tend to be more for elongated basins (Beaumont, 1975), and it is a useful index for hydrograph shape for watershed similar in other respect.

Meticulous study of morphometry of watershed and sub watersheds reveals drainage pattern which further infers to lithogical nature. GIS software has resulted to be of immense utility in the quantitative analysis of the geo-morphometric aspects of the drainage basins. The study reveals that GIS based approach in evaluation of drainage morphometric parameters at basin level is more appropriate than the conventional methods.

The Dd and Fs are the most useful criterion for the morphometric classification of drainage basins that certainly control the runoff pattern, sediment yield and other hydrological parameters of the drainage basin. The Dd of the basin reveals that the nature of subsurface strata is more or less permeable. The presence of high (1.88) drainage density suggesting that it has low permeable sub-soil, and fine drainage texture. High $\mathrm{I}_{\mathrm{f}}$ revealing the low infiltration capacity and high runoff rate. $\mathrm{Rc}, \mathrm{Rf}$ and $\mathrm{Re}$ show the elongated shape of the 
basin and point out the low and delayed discharge of runoff and medium relief of the terrain. Morphometry reveals that the dynamism of watershed morphology is result of natural process and also anthropogenic interference. High relief value (0.78) indicate low infiltration rate and high runoff conditions. Relief ratio values are high in watershed which indicated steep slope and high relief. An extreme high value (1.46) of ruggedness number indicates the area is more prone to soil erosion \& have intrinsic structural complexity in association with relief and drainage density. This analysis reveals that GIS is an effective tool for analysis of morphometric parameter of the basin.

\section{Acknowledgment}

Authors were thankful to authorities of IDE department for their constant encouragement and support and also for giving me the opportunity to work in this project.

\section{References}

Adhikary P. P \& Dash C. J. (2018) Morhometric Analysis of Katra Watershed of Eastern Ghats: A GIS Approach. International Journal Current Microbiological Applied Science Vol.No.7 (3) 1651-1665.

Attri P. K. et al., (2018) Morphometric Analysis of Bhiral Khad Sub-Watershed of Palampur area of Himachal Pradesh by using Remote Sensing and GIS techniques. International Journal of Recent Scientific Research.Vol.No.9 (8) 28275-28279.

Arnab S. \& Prafull S. (2017) Drainage Morphometric Analysis and Water Resource Management of Hindon River Basin, using Earth Observation Data Sets. International Journal of Interdisciplinary Research. Vol.No.3 (4).

Bansod R. \& Ajabe G. (2018) Determination of geomorphological characteristics of Karpri-Kalu watershed using GIS techniques. Journal of Pharmacognosy and Phytochemistry Vol.No.7(1) 19401944.

Hajam R. et al., (2013) Application of Morphometric Analysis for GeoHydrological studies using Geo- Spatial Technology - A Case Study of Vishav Drainage Basin. Hydrology current Research Vol.No. 4. (3).

Javarayigowda N. et al., (2018) Morphometric Analysis of Karadya Micro watershed: A Case Study of Mandya District. American Journal of Remote Sensing Vol.No.6 (1) 15-22.

Kumar G. et al., (2020) Morphometric Analysis and prioritization of Subwatershed in Watershed of Nashik, Maharashtra of Godavari River Basin using Remote Sensing and GIS as a Tool. International Journal of Innovative and Exploring Engineering. Vol.No.8 (4).

Kulkarni M. (2013). The Basic Concept to Study Morphometric Analysis of River Drainage Basin: A Riview. International Journal of Science and Research Vol. No. 4 (7).

Moharir K. \& Pande C. (2014) Analysis of Morphometric Parameters using Remote Sensing and GIS Techniques in the Lonar nala in Akola District, Maharashtra, India. International Journal for Technological Research in Engineering. Vol.No. 1 (10).

Abhilash, M. \& T. Vijaya Lakshmi (2019) Remote Sensing and GIS based Morphometric Analysis for three Subwatershed of Manair river Basin in Telangana, India. Journal of Spatial Hydrology Vol.No.15(2).

Premanand B. \& Satishkumar U. et al., (2018) Morphometric Analysis of Patapur Micro-watershed in North- Eastern Dry Zone of Karnataka Using Geographical Information System: A Case Study. 
International Journal of Current Survanshi S. \& Bhutada S. (2010) Microbiology and Applied Sciences. Vol.No. 7(4) 853-866.

Pareta K. \& Pareta U. (2011) Quantitative Morphometric Analysis of a Watershed of Yamuna Basin, India using Aster (DEM) Data and GIS. International Journal of geomatics and geosciences. Vol.No. 2 (1).

Patil N. P. \& Kadale A. S. et al., (2015) Assessment of Morphometric Characteristics of Karwadi-Nandapur Micro watershed using Remote Sensing and Geographical Information System International Journal of scientific \&Technology Research Vol.No. 4. (04).

Development of thematic maps for a watershed using remote sensing and geographic information system. International Journal of Agricultural Engineering Vol.No.3. (1).

Veeranna J. \& Gouthami K. et al., (2017) Calculating Linear and Areal and Relief Aspect Parameters Using Geo-Spatial Techniques (ArcGIS 10.2 and SWAT model) for Akkeru River Basin Warangal, Telangana, India. International Journal of Current Microbiology and Applied Sciences Vol.No.6 (10) 1803-1809.

\section{How to cite this article:}

Phupate, A. B., V. K. Ingle, H. W. Awari, U. M. Khodke, S. B. Jadhav and Pendke, M. S. 2021. Quantitative Morphometric Analysis using RS and GIS techniques in VNMKV-Pingali Watershed of Pingalgarh Nala Catchment, Parbhani District, Maharashtra, India. Int.J.Curr.Microbiol.App.Sci. 10(12): 258-267. doi: https://doi.org/10.20546/ijcmas.2021.1012.030 